\section{WEEE Recycling: Analysis of Materials Potential Recovery from High-Grade WEEE}

\section{Mohammad Alsheyab*}

Program Manager of Civil and Environmental Engineering - Qatar Foundation, Qatar

*Corresponding author: Mohammad Alsheyab, Program Manager of Civil and Environmental Engineering - Qatar Foundation, Doha, Qatar, Tel: +974 445 48063, Fax: +974 445 48079;E-mail:malsheyyab@gmail.com

Rec date: Apr 17, 2014; Acc date: Apr 28, 2014; Pub date: May 06, 2014

Copyright: (c) 2014Mohammad A, et al. This is an open-access article distributed under the terms of the Creative Commons Attribution License, which permits unrestricted use, distribution, and reproduction in any medium, provided the original author and source are credited.

\begin{abstract}
The traditional consequences of the economic growth are the overuse of natural resources and the generation of waste. Both consequences could cause negative environmental impacts. To achieve a sustainable development, the application of decoupling waste from economic growth could be the solution strategy. This study aims at analyzing the potential of decoupling waste of High Grade -Waste Electrical and Electronic Equipments from economic growth and its impact on saving natural resources and environmental Production. The analysis showed that there was a significant impact on offsetting the consumption of primary material sources from natural resources as well securing a secondary material source with less environmental negative impacts.
\end{abstract}

Keywords: Decoupling; HG-WEEE; Economic growth; Waste and materials recovery

\section{Introduction}

All countries of the world, whether they are developed or developing, aim at enhancing the quality of life of human being, however this enhancement in quality of life leads to more demand (consumption) and this requires higher supply (production). In other words, this means that to achieve an economic growth to improve people quality of life, it has been traditionally unavoidable to consume more natural resources to increase the production in order to satisfy people demand. The current trend in economy growth, quality of life and use of nature is illustrated in Figure 1 where it shows that although there is a substantial gain in economic growth and quality of life, the use of natural resources is being degraded, including mineral resources, renewable resources (e.g. fish), clean drinking water, energy and waste decomposing [1].

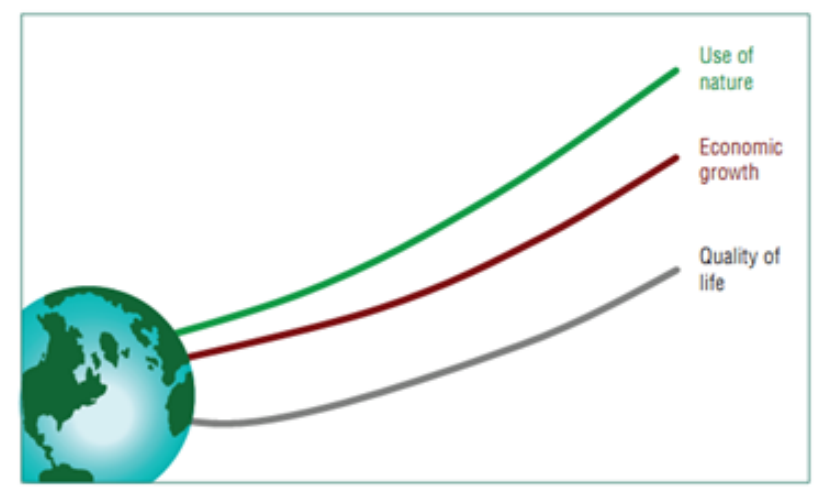

Figure 1: Increase in quality of life has come at the expense of nature [1].
Until now, the earth's natural resources have been sufficient to satisfy the requirements of the economic growth but the earth cannot keep up with the demand of growing economy and this will lead to the overuse of natural resources. According to World Wide Fund for Nature (WWF), we currently use 25\% more than the generative capacity of the planet and it is predicted that this overuse will reach $100 \%$ by 2050 as seen in Figure 2 [2].

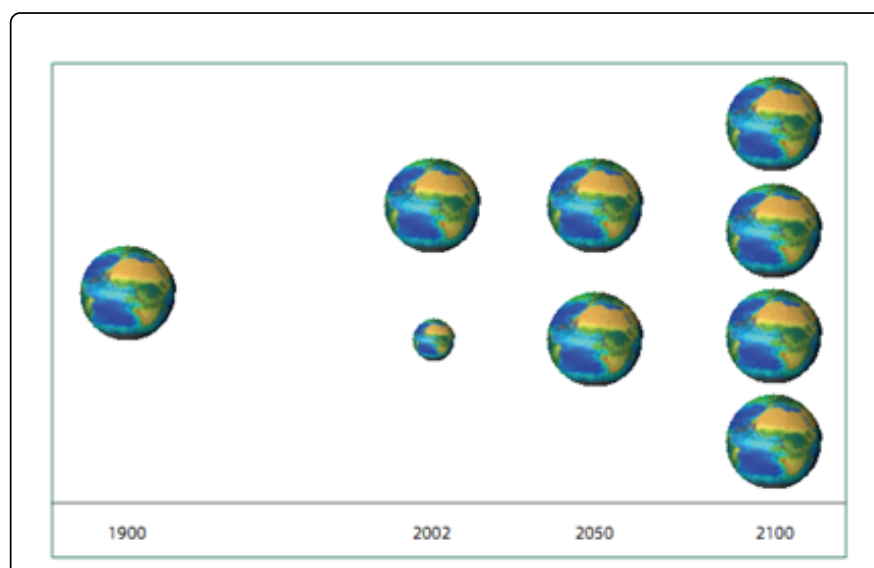

Figure 2: Mankind is overusing the carrying capacity of our planet. By 2050 a $100 \%$ overuse is predicted [2].

The increasing volume of solid waste, caused by the population growth as well as the enhancement of quality of life, is of great environmental concern. The quantities of solid wastes have grown steadily along with the Gross Domestic Products (GDPs). To reduce the correlation between economic growth and waste generation and the related environmental impacts, the EU has put in place a legal framework that follows a two-track approach; on the one hand it requires waste prevention to be the priority measure in waste management so that a decoupling of waste generation and economic growth can be achieved; and on the other hand it encourages the 
member states to promote the reuse and recycling of waste as well as to improve the final disposal and monitoring in order to reduce the environmental damage posed by the different waste streams. It has been reported that waste can be prevented by strict avoidance, reduction at source or reuse and to achieve that the following hierarchy should be followed: (1) Avoid waste production, (2) Waste that cannot be avoided should be minimized, (3) The minimal amount of waste should be recycled, (4) Any waste that is impossible to recycle should be treated and (5) Only then it is fit for disposal in a proper way [3-7].

It has been reported that the strength of a policy measure can be illustrated by achieving a "decoupling scenario" for waste generation compared to a "baseline scenario". The decoupling scenario could be as absolute (no waste growth) or relative (less waste growth than economic growth).

Two main approaches exist for decoupling economic growth and resource consumption along with waste generation: dematerialization and immaterialization. While dematerialization covers all means to reduce the quantity of materials required to generate a desired output (including eco-efficient technologies, recycling) the concept of immaterialization includes changes in the perception of values and criteria of well-being/ standard of living (including education, tourism), and as a consequence changes in behavioural patterns. It is immaterialization which has highest potential to achieve vital progress towards decoupling Figure 3; however chances for implementation will be very specific for given environments (urbanization, economic and political situation, etc.) and require strong interdisciplinary views. Dematerialization has a more distinct technical focus; as a consequence methods are better suited to be directly transferred from one country to another one [7].

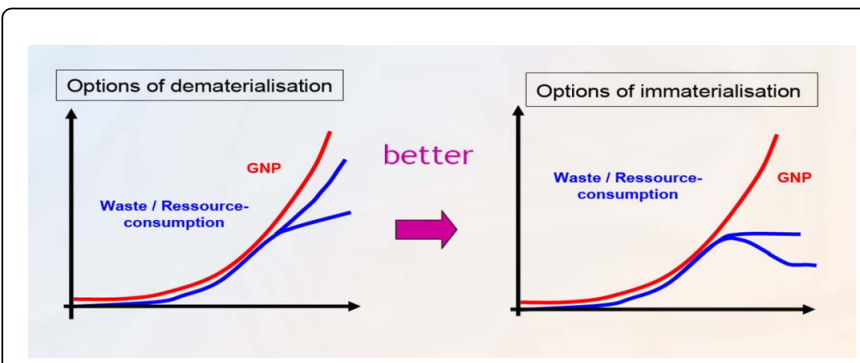

Figure 3: Decoupling of economic growth (GNP - Gross National Product) from waste generation and resource consumption by dematerialization and immaterialization [7]

Therefore the challenge we face now is how to maintain the economic growth but without overusing the natural resources and producing more waste. One of the strategies to achieve that is the decoupling waste from economic growth. This study will focus on the High- grade Waste Electronic and Electrical Equipments (HG-WEEE).

\section{High Grade-Waste Electrical and Electronic Equipments (HG-WEEE)}

The waste electrical and electronic equipment (WEEE) is defined as any appliance using an electric power supply that has reached its endof-life [8] which includes several types of equipments such as: televisions, refrigerators, freezers, washing machines, cloth dryers, air conditioners, personal computers and monitors. Waste electrical and electronic equipment (WEEE) is one of the fastest growing wastes in Europe. The WEEE-Directive, 2002/96/EC [9] listed the WEEE directive in 10 Categories as seen in the following Table 1.

Public waste management authorities should hold the WEEE in collection groups as follows.

- Large household appliance, automatic dispensers.

- Refrigerators and freezers.

- IT and telecommunications equipment.

- Gas discharge lamps

- Small household appliances, lighting equipment, electric and electronic tools, toys, sports and leisure equipment, medical products, monitoring and control instruments.

\begin{tabular}{|l|l|}
\hline Number & Category Name \\
\hline 1 & Large household appliances \\
\hline 2 & Small household appliances \\
\hline 3 & IT and telecommunications equipment \\
\hline 4 & Consumer equipment \\
\hline 5 & Lighting equipment \\
\hline 6 & Electrical \& electronic tools \\
\hline 7 & Toys, leisure and sports equipment \\
\hline 8 & Medical devices \\
\hline 9 & Monitoring and control instruments \\
\hline 10 & Automatic dispensers \\
\hline
\end{tabular}

Table 1: WEEE Directive in 10 categories.

One of the main concerns is the amount of precious and special metals in their production as well as securing their provision which has been viewed as critical [10]. Therefore an increasing attention is paid to the Waste Electrical and Electronic Equipment (WEEE) as a secondary source of metals $[11,12]$. The annual amount of WEEE in 27 countries in 2005 was 8.3-9.1 million metric tons [13], the annual amount of WEEE in United States in 2010 was 8.58 million tons [14] and in Japan 1.7 million tons [15].

In Japan, the treatment of the WEEE consists in collection and recycling. They are separated into materials by manual dismantling and mechanical separation, where plastic materials and materials made of iron, aluminum and copper are recycled and the several precious metals contained in the printed circuit board are recovered.

The WEEE contains several metal values such as: $\mathrm{Fe}, \mathrm{Cu}, \mathrm{Al}, \mathrm{Co}, \mathrm{Ni}$, $\mathrm{Sn}, \mathrm{Pb}$ and $\mathrm{Zn}$ as well as many precious metals such as Gold, Silver and Palladium which enhances the importance of its recycling [16]. Figure 4 shows the life time cycle of EEE. 
Page 3 of 5

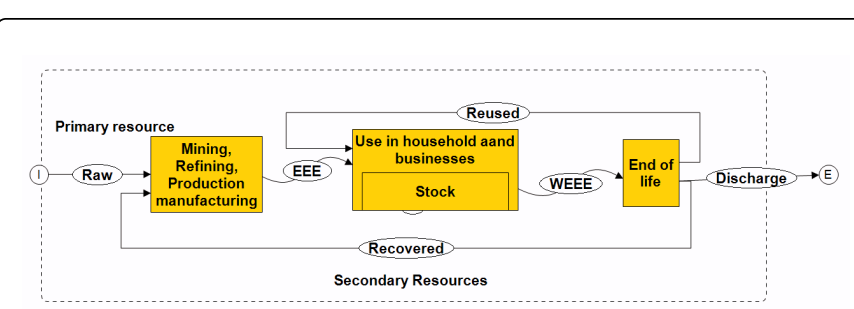

Figure 4: Life cycle of EEE

The HG-WEE includes IT and telecommunication equipments as well as consumer equipment. These are specified below.

It is predicted that the amount of WEEE will keep increasing with the economic growth. A study on European countries by the United Nations University, 2008 Review of Directive 2002/96 on Waste Electrical and Electronic Equipment (WEEE), Final report, Contract No: 07010401/2006/442493/ETU/G4, 05 August 2007. In Table 2 below, the amount of current and predicted WEEE for the biggest 10 economies in Europe [13]

\begin{tabular}{|l|l|l|l|l|l|l|}
\hline Country & 2005 & 2008 & 2010 & 2014 & 2015 & 2020 \\
\hline Germany & $\begin{array}{l}1,425,7 \\
40\end{array}$ & $\begin{array}{l}1,521,5 \\
06\end{array}$ & $\begin{array}{l}1,588,9 \\
12\end{array}$ & $\begin{array}{l}1,732,8 \\
53\end{array}$ & $\begin{array}{l}1,770,8 \\
40\end{array}$ & $\begin{array}{l}1,973,6 \\
81\end{array}$ \\
\hline France & $\begin{array}{l}1,029,4 \\
51\end{array}$ & $\begin{array}{l}1,098,6 \\
82\end{array}$ & $\begin{array}{l}1,147,3 \\
96\end{array}$ & $\begin{array}{l}1,251,3 \\
89\end{array}$ & $\begin{array}{l}1,278,8 \\
26\end{array}$ & $\begin{array}{l}1,425,2 \\
99\end{array}$ \\
\hline $\begin{array}{l}\text { United } \\
\text { Kingdom }\end{array}$ & $\begin{array}{l}1,034,0 \\
90\end{array}$ & $\begin{array}{l}1,103,5 \\
86\end{array}$ & $\begin{array}{l}1,152,5 \\
00\end{array}$ & $\begin{array}{l}1,256,9 \\
37\end{array}$ & $\begin{array}{l}1,284,4 \\
94\end{array}$ & $\begin{array}{l}1,431,6 \\
25\end{array}$ \\
\hline Italy & 970,612 & 29 & $\begin{array}{l}1,035,9 \\
81,08\end{array}$ & $\begin{array}{l}1,179,9 \\
62\end{array}$ & $\begin{array}{l}1,205,8 \\
35\end{array}$ & $\begin{array}{l}1,343,9 \\
36\end{array}$ \\
\hline Spain & 624,401 & 666,546 & 696,165 & 759,336 & 775,990 & 664,814 \\
\hline Netherlands & 282,707 & 301,711 & 315,085 & 343,636 & 351,172 & 391,397 \\
\hline Sweden & 152,67 & 162,936 & 170,159 & 185,580 & 189,649 & 211,370 \\
\hline Poland & 290,233 & 339,335 & 376,652 & 464,165 & 489,075 & 635,319 \\
\hline Belgium & 186,133 & 198,966 & 207,787 & 226,619 & 231,588 & 258,118 \\
\hline Austria & 152,504 & 162,753 & 169,968 & 185,373 & 189,439 & 211,144 \\
\hline
\end{tabular}

Table 2: Forecast household WEEE arisings in the biggest 10 economies in $\mathrm{EU}$ (tons)

\section{IT and telecommunications equipment}

Such as centralised data processing; mainframes; minicomputers; printer units; personal computing; personal computers, including the $\mathrm{CPU}$, mouse and keyboard; laptop computers, including the CPU, mouse and keyboard; notebook computers; notepad computers; printers; copying equipment; electrical and electronic typewriters; pocket and desk calculators; other products and equipment for the collection, storage, processing, presentation or communication of information by electronic means; user terminals and systems; facsimile; telex; telephones; pay telephones; cordless telephones; cellular telephones; answering systems; other products or equipment of transmitting sound, images or other information by telecommunications.

\section{Consumer equipment}

Such as radio sets; television sets; video cameras; video recorders; hi-fi recorders; audio amplifiers; musical instruments; other products or equipment for the purpose of recording or reproducing sound or images, including signals or other technologies for the distribution of sound and image than by telecommunications

\section{Analysis of Germany Case Study: Results and Discussion}

The statistical data from EAR 2011 [17] of the collected amounts of HG-WEEE in Germany showed that the amount of IT and Telecommunication equipments was 151039 tons and the amount of Consumer equipments was 153559 tons, summing up 304598 tons.

Based on a study conducted in Denmark by Marianne B et al. [18], the overall outputs from a pre-treatment plant per $1000 \mathrm{~kg}$ of HGWEEE are shown in Table 3.

\begin{tabular}{|l|l|}
\hline Composition of High Grade WEEE & $\%$ \\
\hline Precious metals & 16,5 \\
\hline Ferrous metals & 38,1 \\
\hline Aluminum & 2,2 \\
\hline Plastic & 26,5 \\
\hline Fluff and residue & 5,3 \\
\hline
\end{tabular}

Table 3: Overall outputs from a pre-treatment of HG-WEEE [17]

By applying the output of the study, shown in Table 2, on the German case to find out the potential of recovery of different components, STAN program was used to determine the different mass flow rates of different components as seen in Figure 5 below.

According to the statistical data from EAR 2011 [17], the collected rate of IT and Telecommunication equipments is $31 \%$ (taking the average of the rate of collection for different components of this category) and $50 \%$ for Consumer equipments, then by using a simple calculation of the real amounts of HG-WEEE in Germany in 2011, the approximate amounts of IT and Telecommunication equipments will be around 487223 tons and the approximate amounts for Consumer equipments will be around 307118 tons, summing up 794341 tons.

If we apply the same results of the study conducted by [16], then the maximum potential recovery will be much higher as seen in Figure 6 .

The potential amounts of recovery from the collected HG-WEE from Germany in 2011, applying the results of the study conducted in Denmark are show in the Table 4.

These amounts can be used as a secondary source of raw material and this will form the cut from the primary source of raw material that would have been produced otherwise. As the above components are much more concentrated in the HG-WEEE than in the primary natural resources, there will be much less generated waste and fuel consumption and consequently less $\mathrm{CO}_{2}$. 

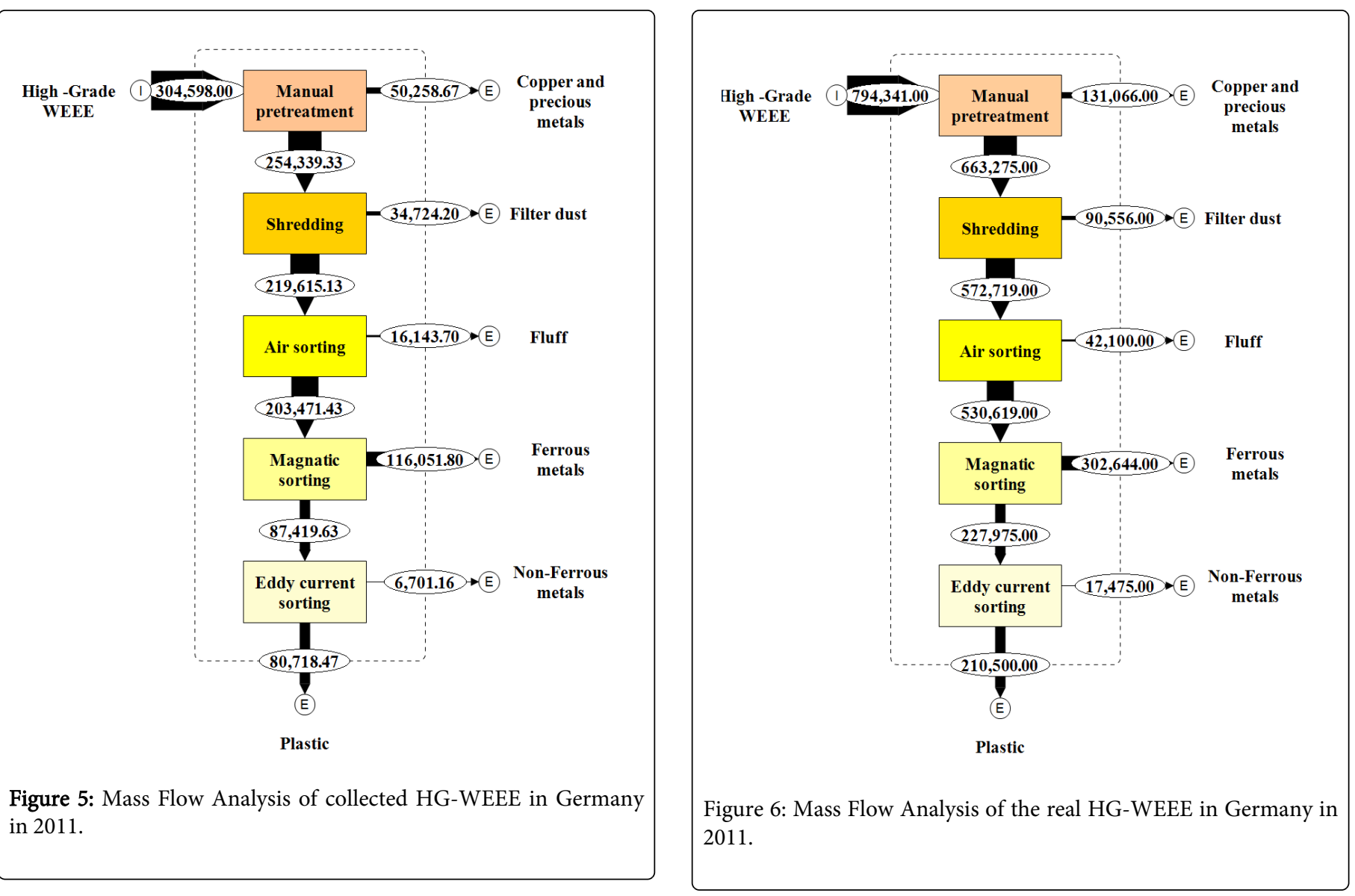

\begin{tabular}{|l|l|l|l|l|}
\hline Copper and precious metals (tons) & Ferrous metals (tons) & Non-Ferrous metals (tons) & Plastics (tons) & Residue (tons) Dust and Fluff \\
\hline 50259 & 116052 & 6701 & 80718 & 50868 \\
\hline
\end{tabular}

Table 4: Recovered amounts from German waste collected in 2011 applying the results of [16].

\begin{tabular}{|l|l|l|l|l|}
\hline Copper and precious metals (tons) & Ferrous metals (tons) & Non-Ferrous metals (tons) & Plastics (tons) & Residue (tons) Dust and Fluff \\
\hline 131066 & 302644 & 17475 & 210500 & 132656 \\
\hline
\end{tabular}

Table 5: Potential recovery of 100\% collection scenario of HG-WEEE in Germany for 2011

If we apply the same results of the study conducted by [16], then the maximum potential recovery is summarised in Table 5 .

The approximate calculations of recovery of different components based on the actual collection rate of HG-WEEE or on the real HGWEEE generated, show that decoupling waste from economic growth could be a significant secondary source of raw material and there is a positive correlation between the efficiency of collection system and the recovery potential.

\section{Conclusions}

- Decoupling waste from economic growth is an efficient strategy for the conservation of natural resources and is a step forward for sustainable development.
- There is appositive correlation between the efficiency of waste collection system and the potential recovery of different waste components.

- The decoupling of waste from economic growth using recycling would secure a secondary source of raw materials which has two main advantages over using primary source of raw materials: (1) Higher concentration of different components and therefore less waste generation and (2) less fuel consumption and therefore less $\mathrm{CO}_{2}$ and other wastes production.

\section{References}

1. WWF One Planet Business - Creating Value within Planetary Limits. 2007 First Edition

2. Resource Efficiency, United Nations Environment Programme 
Citation: Mohammad Alsheyab (2014) WEEE Recycling: Analysis of Materials Potential Recovery from High-Grade WEEE . J Civil Environ Eng

Page 5 of 5

3. Wilson DC (1996) Stick or carrot? The Use of Policy Measures to move Waste Management up the Hierarchy. Waste Manag Res 14: 385-398

4. Cox J, Giorgi S, Sharp V, Strange K, Wilson DC, et al. (2010) Household waste prevention - a review of evidence. Waste Manag Res 28: 193-219.

5. Gottberg A, Longhurst PJ, Cook MB (2010) Exploring the potential of Product Service Systems to achieve household waste prevention on new housing developments in the UK. Waste Manag Res 28: 228-235.

6. Fell D, Cox J, Wilson DC (2010) Future waste growth, modelling and decoupling. Waste Manag Res 28: 281-286.

7. Vogel G (2004) Optionen der europäischen Abfallwirtschaft zur Bewältigung der globalen Ressourcenknappheit - Abfallvermeidung / Dematerialisation / Immaterialisation. Proceedings Wiener Abfallwirtschaftskongress Vienna.

8. Organization for Economic Co-operation and development (OECD) (2001) Extended producer responsibility: A Guidance Manual for Governments. Environment and Sustainable Development 5: 1-159.

9. WEEE-Directive (2002)/96/EC of the European parliament and of the council of 27 January 2003 on waste electrical and electronic equipment (WEEE).

10. UNEP (United Nations Environmental Programme) (2010) Metal Stocks in Society- Scientific Synthesis. UNEP, Paris.
11. Boghe D (2001) Electronic scrap: a growing resource. Met. Bul. Mon.

12. Hagelüken C, Meskers C (2008) Mining our computers - opportunities and challenges to recover scarce and valuable metals from end-of-life electronic devices. In: Proc. Electron. Goes Green 2008+, Berlin.

13. Huisman J, Magalini F, Kuehr R, Maurer C, Ogilvie S et al. (2007) 2008 Review of directive 2002/96 on waste electrical and electronic equipment (WEEE) final report. United Nations University, Bonn.

14. EPA (2010) Municipal Solid Waste in the United States 2009 Facts and Figures. United States Environmental Protection Agency, Washington, DC.

15. Oguchi M, Kameya T, Yagi S, Urano K (2008) Product flow analysis of various consumer durables in Japan. Resour. Conserv. Recycl 52: 463 480 .

16. Cui J, Zhang L (2008) Metallurgical recovery of metals from electronic waste: A review. J. Hazar. Mater 158: 228-256.

17. Indicators, Yearly statistics message.

18. Marrianne Bigum, Line Brogaard, Thomas H, Christensen (2012) Metal Recovery from high-grade WEEE: A life cycle assessment, Journal of Hazardous Materials 207-208: 8-14. 